\title{
Residual Woody Waste Biomass as an Energy Source - Case Study
}

\author{
Franciszek Woch ${ }^{1 *}$, Józef Hernik², Patrycja Wyrozumska ${ }^{3}$, Barbara Czesak ${ }^{2}$ \\ 'Institute of Soil Science and Plant Cultivation, State Research Institute, \\ Czartoryskich 8, 24-100 Puławy, Poland \\ ${ }^{2}$ Department of Land Management and Landscape Architecture, \\ Faculty of Environmental Engineering and Land Surveying, \\ University of Agriculture in Cracow, Balicka 253c, 30-149 Cracow, Poland \\ ${ }^{3}$ The Jan Kochanowski University in Kielce, Świętokrzyska 15, 25-406 Kielce, Poland
}

Received: 13 May 2014

Accepted: 3 September 2014

\begin{abstract}
The aim of our study was to determine the potential of forest woody waste biomass as a source of renewable energy. The research is a case study of one forest division in Poland.

The research was made in Staszów Forest Division, Świętokrzyskie Voivodeship, eastern Poland. The division is part of the Regional State Forest Directorate in Radom and covers a forest area of 19,335.12 ha. The research covers thinning and felling of forests, and was based on the forest management plan for 2012-21 and its inventory data. During the research basic features of forest stands, such as diameter and volume of aboveground, tree parts were determined. The annual growth of a timber stand in $\left[\mathrm{m}^{3} / \mathrm{ha}\right.$ year $]$ and the average age of the stand were analyzed to estimate the amount of obtained wood and biomass for energy generation.

The amount of wood waste that could be used to generate energy is $12,269 \mathrm{t}$ annually both from harvest cutting and intermediate cutting, and additionally 7,267 t/year from wood processing. The energy that could be generated from this amount of woody biomass would allow for electrical power for 14,866 people and heating 3,153 one-family houses for a year. Therefore we claim that the energy obtained from the forest of an area of average rural community meets the needs of half of its inhabitants.
\end{abstract}

Keywords: renewable energy sources, forest biomass

\section{Introduction}

Renewable energy sources are considered to be an important part of Polish strategy for energy security in case of exhaustion of conventional energy sources. Energy security should be understood as sustainable development of renewable energy sources, and providing such security is one of the strategic tasks of the Polish government. Efficient energy management should provide energy not only for the current generation but also for future ones, and minimize the negative impact on the environment [1].

*e-mail: franciszek.woch@iung.pulawy.pl
Currently, the potential for renewable energy in Poland is not fully used, therefore there is a need to support obtaining energy from renewable sources, which positively impacts the environment and creates jobs. Renewable energy sources can also be perceived as a backup in case of a failure in conventional energy supply.

Supporting the development of renewable energy sources has been an important goal of European Union policy [2]. In 1997 the white paper "Energy for the Future: Renewable Sources of Energy" was published. It set a $12 \%$ goal for the share of renewable energy in the gross inland energy consumption that should be achieved by 2010 [3]. But by 2010 the target was not met and energy 
consumption from renewable sources was at $9.8 \%$. The renewable energy directive [4] set the target for 2020 at $20 \%$ for the whole EU. Poland in 2005 used approximately $7 \%$ of energy from renewable energy sources. The national overall target for Poland is $15 \%$ by 2020 but it is still 5\% less than the mandatory target for overall EU energy consumption.

In Poland at the beginning of $20^{\text {th }}$ century, long before coal had become the most popular energy source, wood, including wood residues (brushwood, declining trees) was the main source of energy in rural areas. In addition, the organic waste from agricultural and animal production could be used as an energy source [5]. Currently, it is coal and natural gas that are widely used in rural areas. Therefore, the use of forest residues is limited. Forest residues are left in forests and after decomposition they enrich the soil [6]. Shrinking resources of coal, crude oil, and natural gas, as well as increasing pollution of the environment, could make forest residues an important energy source. Our paper investigates the energy potential of forest residues in Poland on the basis of the data obtained from one forest division (Polish state forests are divided into divisions).

\section{Methodology}

The research was made in Staszów Forest Division, Świętokrzyskie Voivodeship, eastern Poland. The division is part of the Regional State Forest Directorate in Radom and covers 20,204.82 ha, including 19,335.12 ha of forests. The forest division is spread on three poviats (units of local level administration in Poland), i.e., Opatowski, Sandomierski, and Staszowski.

All Polish state forests are managed on the basis of forest management plans for each division. The management plan for Staszów Forest Division for 2012-21 is the main source of the data for Staszów Forest Division covering such data as types of forest habitats (Fig. 1).
Table 1. Harvesting age for dominant tree species [8].

\begin{tabular}{|l|c|}
\hline \multicolumn{1}{|c|}{ Species } & $\begin{array}{c}\text { Harvesting age } \\
\text { [years] }\end{array}$ \\
\hline Scots pine, European larch & 100 \\
\hline Silver fir & 120 \\
\hline European spruce & 80 \\
\hline European beech, European ash & 120 \\
\hline English oak, sessile oak & 140 \\
\hline Northern red oak, clone, sycamore maple & 100 \\
\hline $\begin{array}{l}\text { Silver birch, black alder common hornbeam, } \\
\text { black locust }\end{array}$ & 80 \\
\hline Common aspen & 50 \\
\hline Poplar, white willow & 40 \\
\hline Small-leaved lime & 100 \\
\hline
\end{tabular}

Fresh mixed broadleaved forests cover the largest area of the division. Scots pine (So) is a dominant tree species. It dominates both in coniferous forests and in mixed coniferous forests and covers approximately $71 \%$ of the area. Beech, alder, birch, and fir also are significant. Dominant species have a very good rate of growth and good stand quality (Ia or I stand quality classes). Average age of the stand is 66 years [7].

Forests in the division are divided according to their functions into three groups: reserve forests, protective forests, and industrial forests. Protective forests cover the total area of $9,974.06$ ha $(51.59 \%)$, industrial forests $9,355.10$ ha $(48.38 \%)$, and the reserve forest only 5.96 ha $(0.03 \%)$. Protective forests of the division are divided into 17 categories of protection: soil-protecting, water-protecting, forests in the administrative boarders of cities, forests that are a valuable part of the native woodland, forests located in permanent research areas, high forests that are

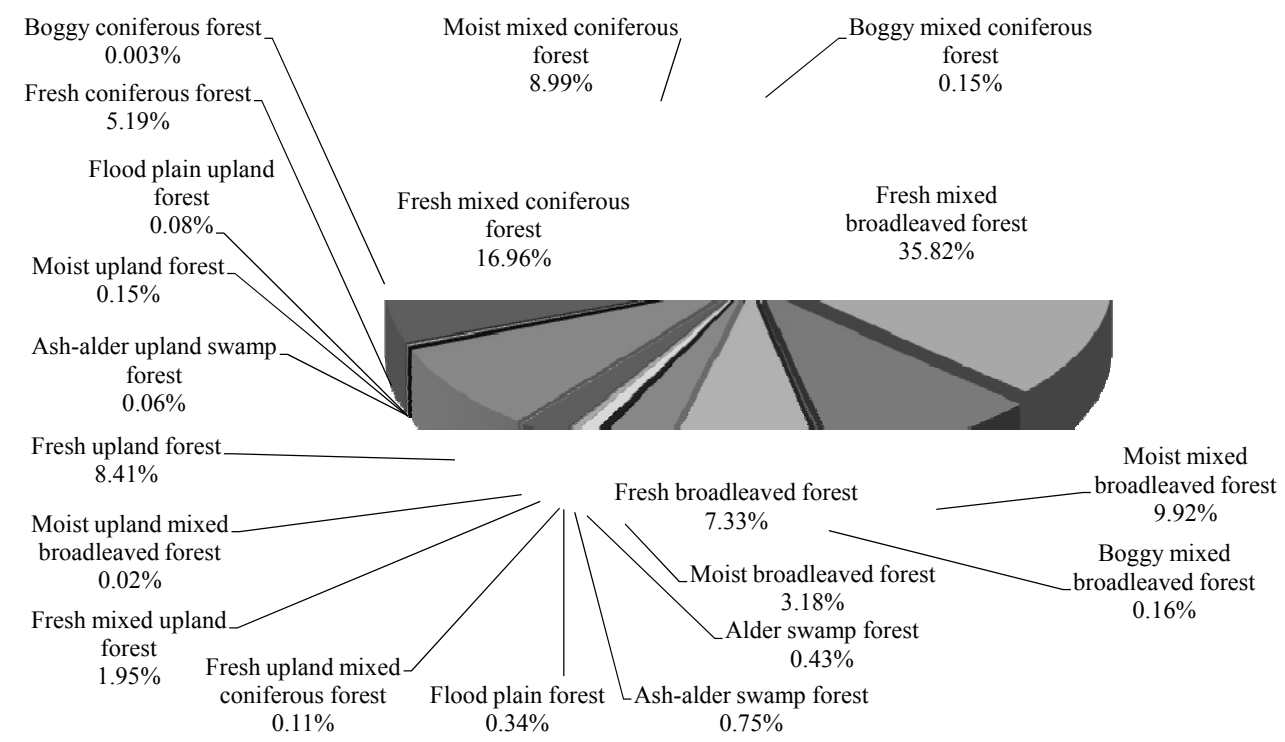

Fig. 1. Forest habitats in Staszów Forest Division [7]. 
Table 2. Basic data on forest stands in the Staszów Forest Division [7].

\begin{tabular}{|l|c|c|}
\hline \multicolumn{1}{|c|}{ Features of forests } & Unit & $\begin{array}{c}\text { Calculated } \\
\text { values }\end{array}$ \\
\hline Mean volume per 1 ha & {$\left[\mathrm{m}^{3} / \mathrm{ha}\right]$} & 258 \\
\hline Gross current annual volume increment & {$\left[\mathrm{m}^{3} / \mathrm{ha}\right]$} & 7.10 \\
\hline Mean age & {$[$ years $]$} & 62 \\
\hline Net intermediate cutting & {$\left[\mathrm{m}^{3} /\right.$ year $]$} & 42392 \\
\hline Net harvest cutting & {$\left[\mathrm{m}^{3} /\right.$ year $]$} & 51906 \\
\hline Reafforestation and afforestation & {$[\mathrm{ha}]$} & 131.46 \\
\hline
\end{tabular}

not harvested, etc. Among protective forests, 3,207.60 ha are under Natura 2000 protection.

Forest stand type, harvest system, and model cropping composition were assigned for each forest habitat during preparation of the management plan for the division. As a result, four methods of management were distinguished:

- Special management (forest reserves, high forests which are not harvested, forests on permanent research areas, soil-protection forests, and water-protection forests)

- Cutting management (stands in which clear cutting was accepted as a management style)

- Cutting-thinning management (stands that are used in a shelterwood system or cutting with 40-year restocking period)

- Thinning management (stands in which improved Swiss femel cutting system with restocking period of over 40 years is applied)

The maturity age for dominant tree species of the division is defined by the Regional State Forest Directorate in Radom (Table 1) [8].

Both intermediate cut stands and harvest cut stands were analyzed on the basis of inventory data from 2002-11 [7]. During the research basic features of forest stands such as diameter and volume of tree parts above ground were determined. The annual growth of a timber stand in $\left[\mathrm{m}^{3} / \mathrm{ha}\right.$ year] and the average age of the stand were analyzed to estimate the amount of obtained wood.

Afterward, the amount of wood residues that could be obtained from forests of the division and used for energy generation was estimated. In order to do so the following formula was applied $[9,10]$ :

$$
Z_{d l}=A \times I \times\left(F_{w} \times F_{e}\right)\left[\mathrm{m}^{3} / \text { year }\right]
$$

...where:

$Z_{d l}-$ wood resources that could be used as an energy source $\left[\mathrm{m}^{3} /\right.$ year]

$A$ - area of forests [ha]

$I \quad-$ annual growth of timber stand $\left[\mathrm{m}^{3} / \mathrm{ha}\right.$ year]

$F_{w}-$ percentage of wood used for industry [\%]

$F_{e}-$ percentage of wood used for energy [\%]

The percentage of wood used for industry implemented in the formula was $55 \%$ of the total wood resources [11] and the percentage of wood used for energy was $25 \%$ of total wood resources [13]. In state forests the percentage of wood used for energy can be determined on the basis of the share of trading sorts used for energy generation in total wood resources [12]. The following trading sorts are considered for energy generation: small dimension heating wood (M2), heating wood (S4), and small side wood (M1). Assuming that wood weight was at the level of $0.65\left[\mathrm{t} / \mathrm{m}^{3}\right]$ [13], the potential resources of wood were calculated.

Waste from wood processing was also considered as an energy source and its amount was estimated on the basis of data from the Staszów Forest Division. The wood waste was determined to be on average $20 \%$ of the input wood mass that is to be processed [9] according to the formula:

$$
Z_{d t}=P \times 0.20[\mathrm{t} / \text { year }]
$$

...where:

$Z_{d t}-$ wood processing by-products that could be used to generate energy [t/year]

$P \quad$ - resources for wood product industry [t]

Total resources estimated with the formulae above (Eq. 1 and Eq. 2) were converted into units of energy, assuming that calorific value of dry wood is $18.72 \mathrm{GJ} / \mathrm{t}$ [9], and at the moisture content of $50 \%$ during the harvest, the calorific value is halved [12]. Average electricity consumption in Poland between 1999 and 2009 was 12.3 GJ per person per year and 58 GJ per family house per year [14]. On the basis of the data the potential of wood waste to meet energy needs of a rural community in Poland was determined.

\section{Results}

The current gross annual volume increments in $\mathrm{m}^{3} / \mathrm{ha}$ was calculated on the basis of the data concerning annual growth of timber in forest stands of the division (Table 2). Then the supply of forest biomass and wood waste was estimated (Eq. 1). After multiplying the area with the annual growth of timber stand and percentage of wood used for industry and percentage of wood used for energy we got $12,269.34$ [t/year].

Assuming that $1 \mathrm{~m}^{3}$ of solid wood with the moisture content of approximately $15 \%$ weighs $700 \mathrm{~kg}$ and assuming that the period in which the wood was obtained is 1 year, the wood processing waste that could be obtained from harvest cutting of industrial forests of the division and used to generate energy is 7,267.0 t/year (Eq. 2).

The total amount of forest biomass for energy purposes includes both wood processing waste and wood waste and gives a total annual amount of forest biomass of 19,536 t/year.

Assuming that calorific value of dry wood is $18.72 \mathrm{GJ} / \mathrm{t}$, the calorific value of wood waste with a harvest moisture at $50 \%$ was determined to be $182,857 \mathrm{GJ} /$ year.

Average energy consumption in Poland between 1999 and 2009 was $12.3 \mathrm{GJ} /$ person/year, annual heat use of a three-person household 58 GJ. Obtained amount of energy could allow for annual lighting for 14,866 people or heating of 3,153 one-family households [14]. The average rural 
community accommodates only half that number of people and only half of the above-number of one-family households. Therefore we can assume that forest waste from the division could meet power and heat needs of a rural community.

Research was made on the basis of the Staszów Forest Management Plan. The assessment of the impact of this plan on Natura 2000 areas showed that provisions of the plan will not damage the biodiversity of Staszów forests [15].

Forests in the division cover an area of 19,335.12 ha, which corresponds to the area of two smaller rural communities. Therefore, we claim that a forest covering an area of an average rural community can meet the energy needs of half of community inhabitants.

\section{Conclusions}

Forests belonging to the Staszów Forest Division have great potential for generating energy from wood waste, which could positively influence the environment. Approximately 19,536 t/year of forest waste, including $12,269 \mathrm{t} /$ year from forests use and 7,267 t/year from wood processing, could be obtained from the industrial forests of the Staszów Forest Division. This amount allows for annual lighting for 14,866 people or heating of 3,153 family households. The forest waste resources of Staszów should meet the power and heat needs of an average Polish rural community. A forest of an area of an average rural community can meet the energy needs of half the inhabitants of the community.

The research shows that in the situation of current forest management which protects some parts of the division (in the total area of 19,335.12 ha as many as 9,974.06 ha $(51.59 \%)$ are covered by protective forests, 5.96 ha $(0.03 \%)$ reserve forests). Obtaining energy may be conducted simultaneously with sustainable management of the forest resources. The results confirm the potential of woody waste biomass that could once again provide people with energy.

\section{References}

1. ABBASPOUR M., KARBASSI A. Energy Demand Model of the Household Sector and Its Application in Developing Metropolitan Cities (Case Study: Tehran). Pol. J. Environ. Stud., 22, (2), 319, 2013.
2. JASIULEWICZ M. Possibility of Liquid Bio-Fuels, Electric and Heat Energy Production from Biomass in Polish Agriculture. Pol. J. Environ. Stud., 19, (3), 479, 2010.

3. COMMUNICATION FROM THE COMMISSION. ENERGY FOR THE FUTURE: RENEWABLE SOURCES OF ENERGY White Paper for a Community Strategy and Action Plan. 1997.

4. DIRECTIVE 2009/28/EC. Directive 2009/28/EC of the European Parliament and of the Council of 23 April 2009 on the promotion of the use of energy from renewable sources

5. NAWALANY G., BIEDA W., RADON J., HERBUT P. Experimental study on development of thermal conditions in ground beneath a greenhouse. Energy and Buildings., 69, 103, 2014.

6. WOCH F., HERNIK J., PIÓRO P. The possibility of the energy use of forest biomass waste evaluation on the example of the selected forest inspectorate. Energetyka i Ochrona Środowiska, Monografie., 61, 283, 2013.

7. STASZÓW FOREST DIVISION. Forest Management Plan for Staszów Forest Division. for 2012-2021. no date. [In Polish]

8. www.radom.lasy.gov.pl [online]. [accessed. 14. July 2013]. Retrieved from: www.radom.lasy.gov.pl

9. BUCZEK J., KRYŃSKA B. Biomass resources - rules and indicators for creating the balance of biomass. In: Mat. szkol., Innowacje w technologiach roślinnych podstawą kształtowania rolniczej przestrzeni produkcyjnej przez samorząd terytorialny. Rzeszów: Uniwersytet Rzeszowski, pp. 1-8, 2007 [In Polish].

10. BUCZEK J., KRYŃSKA B., TOBIASZ-SALACH R. The evaluation of woody biomass for energetic purposes in Podkarpackie Voivodeship. In: Innowacje w technologiach roślinnych podstawą kształtowania rolniczej przestrzeni produkcyjnej przez samorząd terytorialny. B.m.: Wydawnictwo Uniwersytetu Rzeszowskiego, pp. 132-149, 2008 [In Polish].

11. IBMER. Energy planning on local and regional level including renewable sources of energy. 2002 [In Polish].

12. KOWALCZYK-JUŚKO A. Methodology of estimating the regional sources of biomass for energy purposes. Zeszyty Naukowe SGGW., 18, 103, 2010 [In Polish].

13. EUROPEJSKIE CENTRUM ENERGII ODNAWIALNEJ. The demand for biomass for energy purposes for 20062014. 2006 [In Polish].

14. CENTRAL STATISTICAL OFFICE OF POLAND. Fuel energy economy. no date [In Polish].

15. BUREAU FOR FOREST MANAGEMENT AND GEODESY - RADOM. The estimated impact of the forest management plan for the district Staszów on the environment and Natura 2000 areas. pp. 1-166, 2012 [In Polish]. 